\title{
Peat and coconut fiber as biofilters for chromium adsorption from contaminated wastewaters
}

\author{
Kołoczek Henryk $^{1}$ • Chwastowski Jarosław ${ }^{1} \cdot$ Żukowski Witold ${ }^{2}$
}

Received: 15 June 2015 / Accepted: 19 August 2015 / Published online: 29 August 2015

(C) The Author(s) 2015. This article is published with open access at Springerlink.com

\begin{abstract}
Batch adsorption experiments were performed for the removal of chromium (III) and chromium (VI) ions from aqueous solutions using Canadian peat and coconut fiber. The Langmuir model was used to describe the adsorption isotherm. The maximum adsorption for peat reached $18.75 \mathrm{mg} /$ $\mathrm{g}$ for $\mathrm{Cr}(\mathrm{III})$ and $8.02 \mathrm{mg} / \mathrm{g}$ for $\mathrm{Cr}(\mathrm{VI})$, whereas the value for fiber was slightly higher and reached $19.21 \mathrm{mg} / \mathrm{g}$ for $\mathrm{Cr}(\mathrm{III})$ and $9.54 \mathrm{mg} / \mathrm{g}$ for $\mathrm{Cr}(\mathrm{VI})$. Both chromium forms could be easily eluted from the materials. The adsorption of chromium forms to organic matter could be explained in terms of formation of donor-acceptor chemical covalent bound with hydrox$\mathrm{yl}$ groups as ligands and chromium as the central atom in the formed complex. The chromate-reducing activities were monitored with the use of electron paramagnetic resonance spectroscopy. The results showed that both adsorption and reduction occurred simultaneously and the maximum adsorption capacity of hexavalent chromium being equal to $95 \%$ for fiber and $92 \%$ for peat was obtained at $\mathrm{pH} 1.5$. The reduction of $\mathrm{Cr}(\mathrm{VI})$ in wastewaters began immediately and disappeared after $20 \mathrm{~h}$. Both materials contained yeast and fungi species which can be responsible for reduction of chromium compounds, due to their enzymatic activity (Chwastowski and Koloczek (Acta Biochim Pol 60: 829-834, 2013)). The reduction of $\mathrm{Cr}(\mathrm{VI})$ is a two-phase process, the first phase being rapid and based on chemical reaction and the second phase
\end{abstract}

Responsible editor: Philippe Garrigues

Kołoczek Henryk

koloczek@chemia.pk.edu.pl

1 Department of Inorganic Technology and Environmental Biotechnology, Cracow University of Technology, Krakow, Poland

2 Faculty of Chemical Engineering and Technology, Cracow University of Technology, Krakow, Poland having biological features. After the recovery step, both types of organic materials can be used again for chromium adsorption without any loss in the metal uptake. Both of the materials could be used as biofilters in the wastewater treatment plants.

Keywords Canadian peat · Coconut fiber · $\mathrm{Cr}(\mathrm{III}) \cdot \mathrm{Cr}(\mathrm{VI})$. Adsorption $\cdot$ Reduction $\cdot$ Kinetics

\section{Introduction}

The discharge of heavy metals in effluents is one of the effects of increasing industrialization that contaminates the environment (Balan et al. 2009; Sollitto et al. 2010; Singh et al. 2004). The environmental pollution by chromate $\left(\mathrm{Cr}^{6+}, \mathrm{CrO}_{4}{ }^{2-}\right)$ is a result of its wide use in industry (tanning, corrosion control, plating, pigment manufacture, and nuclear energy). $\mathrm{Cr}(\mathrm{VI})$ is the second most important heavy metal-based pollutant regarded as a priority contaminant by the US EPA (the concentrations of which reach up to $0.18 \mathrm{mM}$ in groundwater and up to $70 \mathrm{mM}$ in soil, according to the US Department of Energy, 2001). The adverse health effects and diverse cellular and molecular reactions make the studies on chromium toxicology and metabolism very crucial in terms of environmental protection and clinical medicine. The toxic action of $\mathrm{Cr}(\mathrm{VI})$ arises from its single-electron reduction by flavoenzymes and other redox reactions, i.e., the formation of $\mathrm{Cr}(\mathrm{V})$ which initiates the formation of reactive oxygen species (ROS) damaging phospholipids, proteins, and DNA (Stearns and Wetterhahn 1994; Levina and Lay 2004). Chromium compounds are some of the best-documented mutagens and carcinogens among the variety of toxic metal compounds used in industry (Chwastowski and Kołoczek 2013; Yuan et al. 2010). The stable oxidation states of chromium are $\mathrm{Cr}(\mathrm{VI})$ and $\mathrm{Cr}(\mathrm{III})$ found in different forms depending on $\mathrm{pH}$ values (Balan et al. 
2009; Mohan and Pittman 2006; Silva et al. 2008). In spite of lower toxicity of $\mathrm{Cr}(\mathrm{III})$ compared to $\mathrm{Cr}(\mathrm{VI})$, both of the metal forms are harmful. At higher concentrations $\mathrm{Cr}$ (III) can also cause adverse health effects because it can coordinate different organic compounds, resulting in inhibition of metallic-enzyme systems (Kotas and Stasicka 2000). The limit for aqueous effluents discharged into waters is about $2 \mathrm{mg} / \mathrm{l}$ depending on the country (European Directive 80/778/EC, 1980). Several technologies have been explicated to remove various metals from industrial wastewater, mainly from tannery factories. Although the tannery wastewater contains much more $\mathrm{Cr}$ (III) than $\mathrm{Cr}(\mathrm{VI})$, under certain circumstances, $\mathrm{Cr}(\mathrm{III})$ may be oxidized to $\mathrm{Cr}(\mathrm{VI})$, a process that can lead to serious environmental consequences (Gomez and Callao 2006). The corresponding oxidation of $\mathrm{Cr}(\mathrm{IIII})$ to $\mathrm{Cr}(\mathrm{VI})$ occurs, particularly in the presence of $\mathrm{MnO}_{2}$ and bacteria, but kinetics of the oxidation is slow (Richard and Bourg 1991). For these reasons, simultaneous removal of the oxidized and reduced forms of chromium is of special interest. Many of these processes are complicated, generate wastes, and may be expensive, ineffective, and time consuming. Peat and coconut fiber are inexpensive and widely available natural materials. They consist of different types of organic matter at various stages of decomposition like cellulose, humic and fulvic acids, or lignin. These components contain hydroxyl and weak acidic groups, such as carboxyl and phenolic hydroxide, which can be involved in chemical bonding of metals and polar organics (Balan et al. 2009). The ability of peat to remove various heavy metals like chromium, cadmium, nickel, lead, and copper has been reported by many authors (Brown et al. 2000; da Cerqueira et al. 2012). Typical chromium concentration in tannery wastewater ranges from 170 to $200 \mu \mathrm{g} / \mathrm{g}$ (Milacic and Stupar 1995) which is far lower than the concentration used in this study. High concentration of chromium was used in order to check the maximum possible adsorption on the organic materials. Additionally, the adsorption of both chromium forms and reduction of $\mathrm{Cr}(\mathrm{VI})$ in tannery wastewaters (probes taken from the tannery station-southern part of Poland) in the presence of the organic sorbents were observed. The measurements of hexavalent chromium reduction in the wastewaters by coconut fiber and Canadian peat were conducted for the first time. In this study, the sorption capacity of the commercially available Canadian peat and coconut fiber for both chromium (III) and chromium (VI) ions in the concentration equal to $10 \mathrm{mM} / \mathrm{L}$ was investigated.

\section{Materials and methods}

Chemicals and reagents used were of high-purity grade. Stock solutions of $10 \mathrm{mM} \mathrm{Cr}(\mathrm{VI})$ and $10 \mathrm{mM} \mathrm{Cr}(\mathrm{III})$ were prepared using solid $\mathrm{K}_{2} \mathrm{Cr}_{2} \mathrm{O}_{7}$ and $\mathrm{CrCl}_{3} \cdot 6 \mathrm{H}_{2} \mathrm{O}$ then dissolved in demineralized water.

\section{Preparation of Canadian peat and coconut fiber}

In this study, commercially available Canadian peat (bought from the SpillSorb Company) and coconut fiber (bought from the market) were used. Both materials were washed three times with the use of distilled water until the filtrate was clear, then air-dried at room temperature, and sieved through a 100mesh grid. In order to improve the dissociation of carboxylic groups from both peat and coconut fiber, probe samples of $1 \mathrm{~g}$ were treated for $12 \mathrm{~h}$ with $10 \mathrm{ml}$ of $0.1 \mathrm{M} \mathrm{NaCl}$ solution (Balan et al. 2009). After $12 \mathrm{~h}$, the probes were centrifuged at $3000 \mathrm{rpm}$ for $10 \mathrm{~min}$ and the supernatant was discarded. The solid residue was taken for further experiments.

Microbiological tests were performed in order to check whether the material contained microorganisms. Five grams of each material was separately added to two 250 -ml flasks. Fifty milliliters of demineralized water was added to the flasks and then the probes were stirred for $3 \mathrm{~h}$ at the room temperature. In order to acquire the supernatant, the probes were centrifuged at $3000 \mathrm{rpm}$ for $10 \mathrm{~min}$. The obtained solution was diluted with water and cultured in Petri dish containing $10 \mathrm{ml}$ of growth medium YPD (yeast extract, peptone, dextrose). The composition of YPD was as follows: peptone, 20; yeast extract, 10; saccharose, 20; agarose, 20 ( $\mathrm{g} / 1$ of medium). After the 7 days of incubation, the probes were examined using a microscope. Both of the organic materials contained yeast species, moreover the coconut fiber contained fungi species.

\section{$\mathrm{pH}$ as an influencing factor for removal of $\mathrm{Cr}(\mathrm{VI})$ and $\mathrm{Cr}$ (III)}

Portions of $10 \mathrm{ml}$ of $\mathrm{Cr}(\mathrm{VI})$ solution with different $\mathrm{pH}$ were transferred into the solid phase extraction columns with $1 \mathrm{~g}$ of Canadian peat and $1 \mathrm{~g}$ of coconut fiber, respectively. The $\mathrm{pH}$ of the solutions were adjusted to the following values: 1.5, 2.5, $3,4,5$, and 6 using pH-meter and appropriate amounts of $1 \mathrm{M}$ $\mathrm{HCl}$ solution. A control sample (pH 4.8) was prepared by adding $\mathrm{Cr}(\mathrm{VI})$ without $\mathrm{HCl}$ addition. The same steps were taken for $\mathrm{Cr}(\mathrm{III})$ solution. Batch adsorption experiments were carried out in 10-ml SPE columns (solid phase extraction) with the same flow rate in each probe $(0.1 \mathrm{ml} / \mathrm{s})$.

\section{Determination of $\mathrm{Cr}(\mathrm{VI})$ and $\mathrm{Cr}(\mathrm{III})$ in filtered solution}

The concentrations of $\mathrm{Cr}(\mathrm{VI})$ and $\mathrm{Cr}(\mathrm{III})$ were determined in the filtrates. The amount of metal adsorbed on the material was determined as the difference between concentration of stock solution and the concentration of the measured filtrate. Concentration of $\mathrm{Cr}(\mathrm{VI})$ was determined with a spectrophotometer at a wavelength equal to $376 \mathrm{~nm}$ for $\mathrm{Cr}(\mathrm{VI})$ and $601 \mathrm{~nm}$ for $\mathrm{Cr}(\mathrm{III})$, respectively. 
Table 1 CHN analysis and estimated chemical composition of both organic materials: peat and coconut fiber

\begin{tabular}{|c|c|c|c|c|c|c|c|}
\hline Probe & $\mathrm{C}(\%)$ & $\mathrm{H}(\%)$ & $\mathrm{N}(\%)$ & $\mathrm{O}(\%)$ & Protein $(\%)$ & Carbohydrates (\%) & Other inactive organic material (\%) \\
\hline \multirow[t]{3}{*}{ Peat } & 48.6 & 5.0 & 1.3 & 45.1 & 8.0 & 84.6 & 7.5 \\
\hline & 48.7 & 5.2 & 1.2 & 44.9 & 7.7 & 84.1 & 8.1 \\
\hline & 48.6 & 5.1 & 1.3 & 45.0 & 7.8 & 84.3 & 7.8 \\
\hline \multirow[t]{3}{*}{ Coconut fiber } & 46.6 & 4.5 & 0.6 & 48.2 & 4.0 & 90.4 & 5.6 \\
\hline & 46.9 & 4.7 & 0.6 & 47.8 & 4.0 & 89.6 & 6.4 \\
\hline & 46.8 & 4.6 & 0.7 & 48.0 & 4.1 & 90.0 & 5.9 \\
\hline
\end{tabular}

Results presented at moisture-free state and ash

\section{Determination of $\mathrm{Cr}(\mathrm{VI})$ and $\mathrm{Cr}(\mathrm{III})$ in wastewater}

Wastewater taken from the wastewater treatment plant located in the south of Poland was centrifuged at $5000 \mathrm{rpm} / \mathrm{min}$ for $10 \mathrm{~min}$. The supernatant was tested for the presence of $\mathrm{Cr}(\mathrm{VI})$ by means of absorption after the reaction with 1,2diphenylocarbazide at a wavelength of $546 \mathrm{~nm}$. The total amount of chromium was determined using the atomic absorption spectroscopy with a Perkin Elmer spectrophotometer. The concentration of trivalent chromium was calculated as the difference between the concentration of total chromium and hexavalent chromium.

\section{Electron paramagnetic resonance spectroscopy}

In order to investigate reduction processes the experiments were performed at a room temperature using $0.1 \mathrm{~g}$ of sorbent and $1 \mathrm{ml}$ of chromium solution. The reduction process was

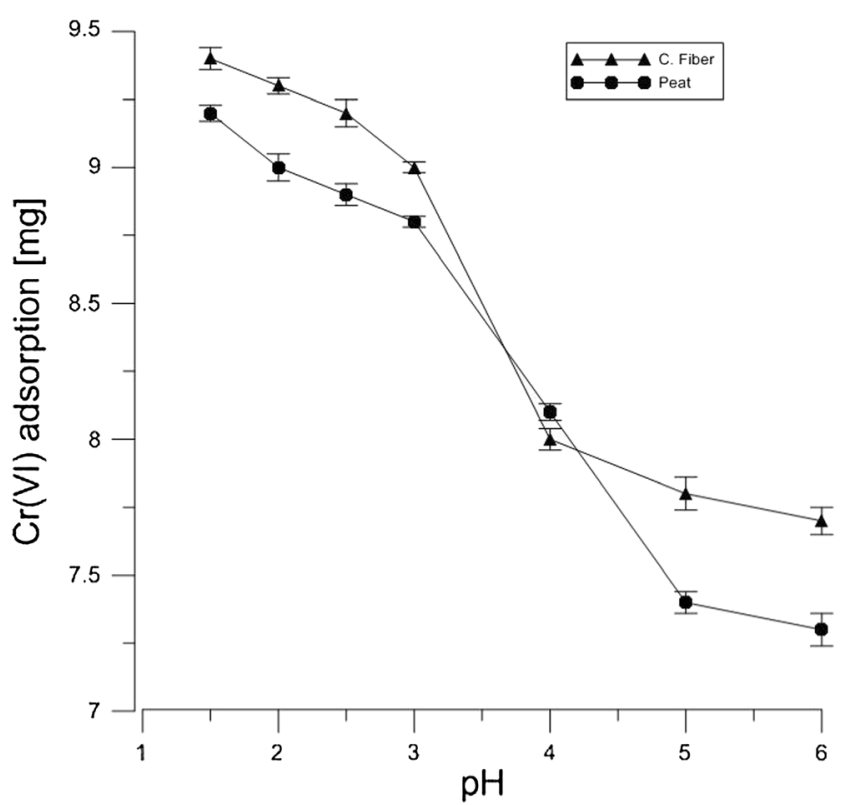

Fig. 1 Adsorption of $\mathrm{Cr}(\mathrm{VI})$ solution in $20 \mathrm{~min}$ by $1 \mathrm{~g}$ of peat and coconut fiber as $\mathrm{pH}$ function. The concentration of stock solution was equal to $10 \mathrm{mM}$ carried out during 120 min with the initial concentration of $\mathrm{Cr}(\mathrm{VI})$ equal to $10 \mathrm{mM}$ in each probe. The kinetics of chromate reduction was monitored by means of $\mathrm{Cr}(\mathrm{V})$ free radical form determination of spectra using L-band $(1.2 \mathrm{GHz})$ electron paramagnetic resonance (EPR). The spectrometer was equipped with a microwave bridge with the operating frequency of $1.2 \mathrm{GHz}$ and an extended surface coiltype high frequency resonator having an internal diameter of $16 \mathrm{~mm}$. The following settings of the spectrometer were typically used: $30 \mathrm{~mW}$ maximum microwave power, $27 \mathrm{kHz}$ field modulation frequency, $40 \mathrm{G}$ magnetic field scan. The scan of the spectra was recorded five times for each measurement and averaged. Every EPR signal was standardized to the free-radical probe (TEMPO) at constant concentration. The spectrum of the probe was taken at the beginning of each measurement. The procedure allows to compare amplitudes of all EPR signals for all the samples.

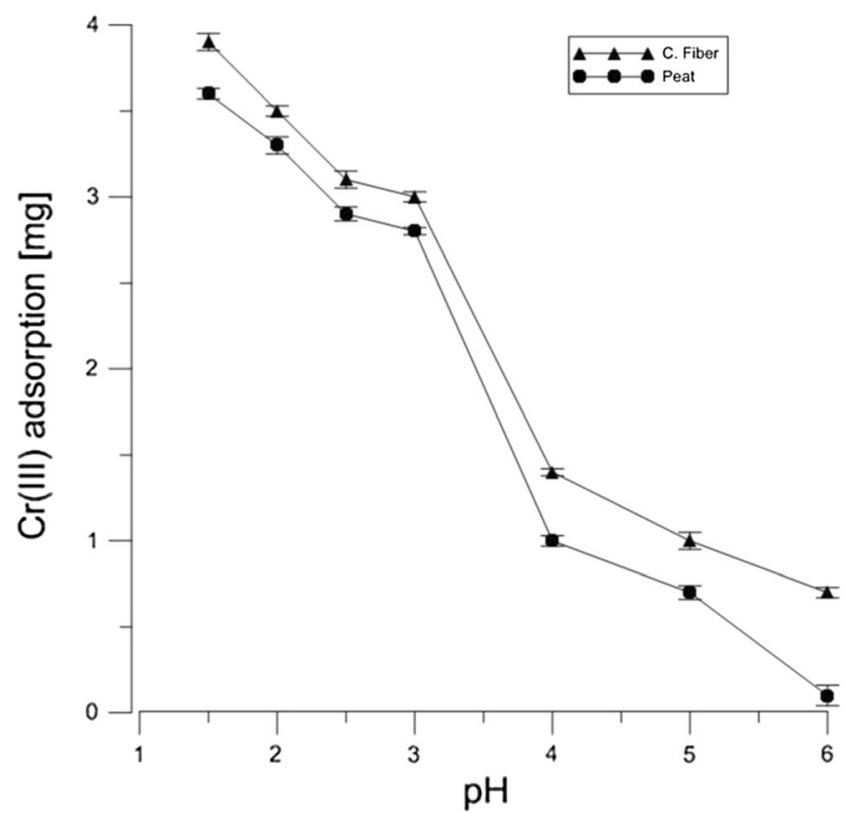

Fig. 2 Adsorption of $\mathrm{Cr}(\mathrm{III})$ solution in $20 \mathrm{~min}$ by $1 \mathrm{~g}$ of peat and coconut fiber as $\mathrm{pH}$ function. The concentration of stock solution was equal to $10 \mathrm{mM}$ 
Scheme 1 Mechanism of the $\mathrm{Cr}^{+}$ ${ }^{6}$ ions interaction with hydroxyl groups of organic material in acid conditions

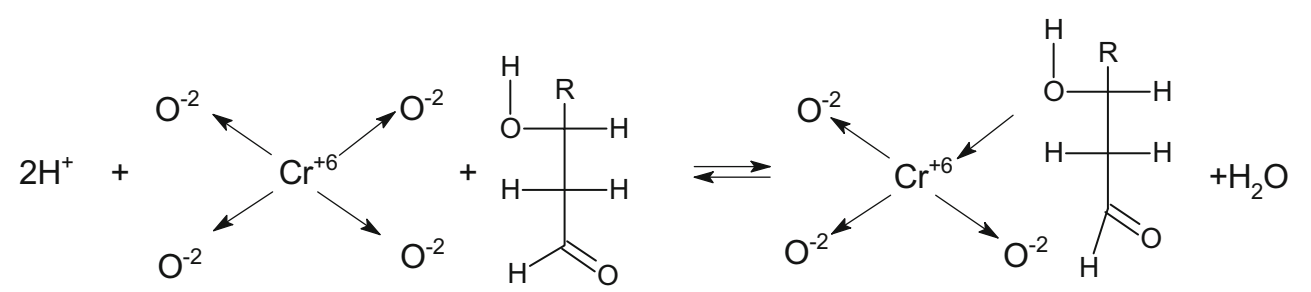

\section{Results and discussion}

The percentage analyses of peat and coconut organic elements were carried out with Perkin Elmer CHN analyzer type 2400. The measurements were supplemented with an additional analysis to specify moisture and ash content in the samples and carbon, hydrogen, and nitrogen ( $\mathrm{CHN}$ ) composition based on ash and moisture-free state was calculated. Averaged results on the basis of triple repetitions are presented in Table 1. In order to determine chemical characteristics of the organic matter included in Canadian peat and coconut fiber, mass fractions of $\mathrm{C}, \mathrm{N}$, and $\mathrm{H}$ in ash and moisture-free states were taken into account and mass fractions of protein, carbohydrate, and residual organic content represented as $\mathrm{CH}_{2}$ were estimated according to stoichiometric calculations. Table 1 shows the obtained results.

Figures 1 and 2 show the adsorption process of both hexavalent and trivalent chromium on Canadian peat and coconut fiber at $\mathrm{pH}$ values ranging from 2.0 to 6.0 . The percentage adsorption of $\mathrm{Cr}(\mathrm{VI})$ and $\mathrm{Cr}(\mathrm{III})$ in aqueous solution showed high influence of the $\mathrm{pH}$ on the adsorption process, e.g., the uptake for peat and coconut fiber at $\mathrm{pH} 1.5$ was equal to 93 and $95 \%$, respectively. Similar tendency can be observed for the $\mathrm{Cr}(\mathrm{III})$. Organic content is higher by about $5 \%$ in fiber compared to peat. The similar results were seen in the case of carbohydrates. The different concentration of the groups in each material can be responsible for the adsorption difference between peat and coconut fiber as presented in Figs. 1 and 2.

The proposed explanation of interactions between the hydroxyl groups and the central ion of the chromium complexes can be related to the electronic structure of the chromate anion according to the reaction (Scheme 1):

After elimination of the oxygen atom, the free orbital of chromium is able to accept an unbound electron pair. It can originate from the oxygen atom of the hydroxyl group of an organic sorbent. As a result of the interaction, chromium sorption occurs and the donor-acceptor reaction (1) is strongly related to $\mathrm{pH}$ due to the Le Chatelier's principle.

Such a donor-acceptor reaction induces an additional interaction between chromium complex oxygen ion and other carbonyl or hydroxyl groups of the sorbent, which results in the reduction of central chromium ion as chemical consequences.

The adsorption process of $\mathrm{Cr}(\mathrm{VI})$ followed by its reduction to $\mathrm{Cr}(\mathrm{III})$ was also detected on magnetite nanoparticles (Yuan et al. 2009).

A more complicated mechanism can be noticed for chromium (III) cation, where series of chemical equilibria are related.

On the one hand, hydrolysis of the cation leads to various kinds of complexes $\left[\mathrm{Cr}(\mathrm{OH})_{n}\left(\mathrm{H}_{2} \mathrm{O}\right)_{m}\right]^{+3-n}$, where $n+m=6$ at higher $\mathrm{pH}$. On the other hand, at low $\mathrm{pH}$, a dominant form of chromium with $n=0, m=6$ is observed and all of the aqualigands are weakly bound to $\mathrm{Cr}$. In this situation, free electron pairs from organic material hydroxylic groups can compete with water molecules more effectively than with hydroxide anion and can chelate the central $\mathrm{Cr}$ ion. As the result, the adsorption which depends on the $\mathrm{pH}$ value occurs again. The high $\mathrm{pH}$ values, $n=2$ and $m=4$, make this form of complex dominant due to competition between $\mathrm{OH}^{-}$and water molecules. At high $\mathrm{pH}$, the equilibrium reaction is shifted to the complex of $\mathrm{Cr}$ and $\mathrm{OH}^{-}$. It results in the fact that the adsorption of the $\mathrm{Cr}^{+3}$ onto the organic material is negligible.

The above-mentioned explanation constitutes only one aspect of the adsorption mechanisms. The other, in which carboxylic and amine groups are involved, is discussed below.

According to the literature data, the adsorption of both $\mathrm{Cr}$ forms on the peat and coconut fibers is effective at as low $\mathrm{pH}$ as 1.5 (da Cerqueira et al. 2012; Nakayasu et al. 1999). However, such low $\mathrm{pH}$ is not preferred as far as the wastewater treatment process is concerned because it requires the use of large amounts of reagents necessary to obtain a low $\mathrm{pH}$ and $\mathrm{pH}$-adjusting reagents to the neutral range at the final stage of the effluent treatment. Therefore, the data presented in Table 2

Table 2 Parameters for the sorption of $\mathrm{Cr}(\mathrm{VI})$ and (III) on Canadian peat

\begin{tabular}{|c|c|c|c|c|}
\hline \multicolumn{2}{|c|}{ Isotherm parameter } & \multirow{2}{*}{$\begin{array}{l}\text { Peat }+\mathrm{Cr}(\mathrm{VI})(\mathrm{pH}=4.5) \\
8.02\end{array}$} & \multirow{2}{*}{$\begin{array}{l}\text { Peat }+\mathrm{Cr}(\mathrm{III}) \\
(\mathrm{pH}=4.5) \\
16.72\end{array}$} & \multirow{2}{*}{$\begin{array}{l}\text { Peat }+\mathrm{NaCl}+\mathrm{Cr}(\mathrm{III}) \\
(\mathrm{pH}=4.5) \\
18.75\end{array}$} \\
\hline Langmuir & $q_{0}(\mathrm{mg} / \mathrm{g})$ & & & \\
\hline & $K_{L}(1 / \mathrm{mg})$ & 0.004 & 0.0009 & 0.001 \\
\hline & $R^{2}$ & 0.997 & 0.998 & 0.998 \\
\hline
\end{tabular}


describe chemical parameters of the adsorption process at $\mathrm{pH}$ 4.5. The Langmuir sorption isotherms of both chromium III and VI on Canadian peat (and NaCl-treated form) are shown in Figs. 3, 4, and 5. The experiments were done in the presence of $100 \mathrm{mM} \mathrm{NaCl}$, in which case stronger adsorption was observed in comparison with tests carried out without the use of the salt (data not shown). It was assumed that the distribution of chromium ions was described by sorption isotherms which illustrated the distribution of adsorbate species between the solid phase and the liquid phase in equilibrium state.

The Langmuir isotherm adsorption model is based on the assumption that maximum adsorption corresponds to a monolayer of solute species on the sorbent surface, containing a finite number of energetically equivalent sites. The equation can be used in the following linearized form:

$\frac{1}{q}=\frac{1}{q_{0} K_{L} L_{C}}+\frac{1}{q_{0}}$

where

$q$ the amount of solute adsorbed on the material at equilibrium $(\mathrm{mg} / \mathrm{g})$

$q_{0} \quad$ maximum amount of solute adsorbed $(\mathrm{mg} / \mathrm{g})$

$K_{L} \quad$ constant related to the binding energy of the solute $(1 / \mathrm{mg})$

$L_{C} \quad$ concentration of $\mathrm{Cr}$ in solution after equilibrium

The parameters of Langmuir isotherm were evaluated from the slope and the intercept of the corresponding plots and they are summarized in Table 2.

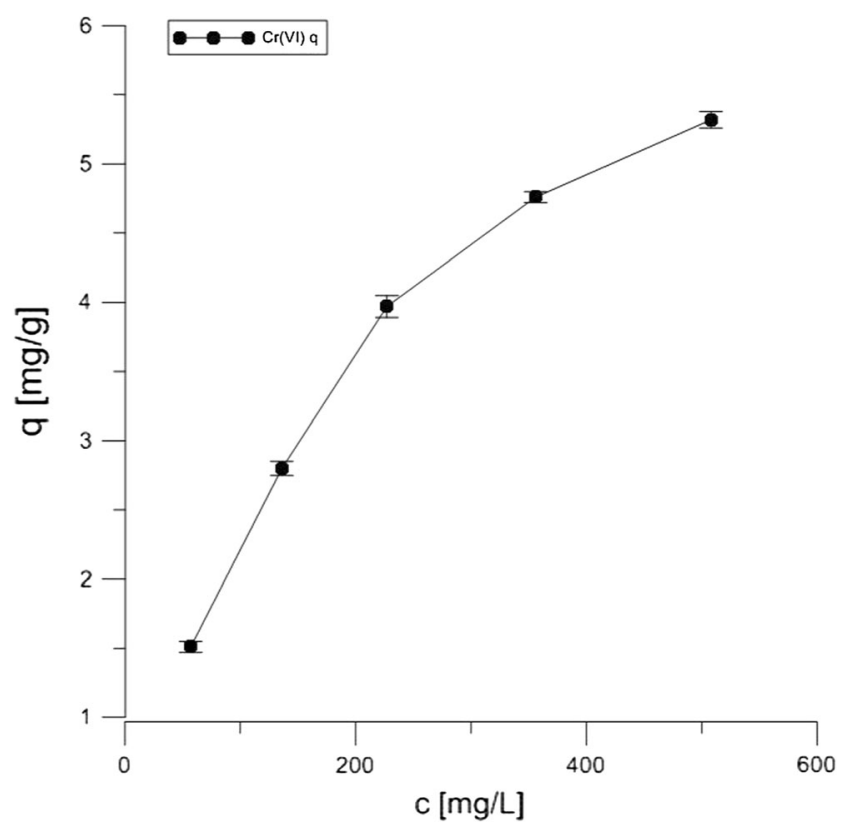

Fig. 3 Langmuir isotherm of $10 \mathrm{mM} \mathrm{Cr}(\mathrm{VI})$ onto peat during $20 \mathrm{~h}$ of contact

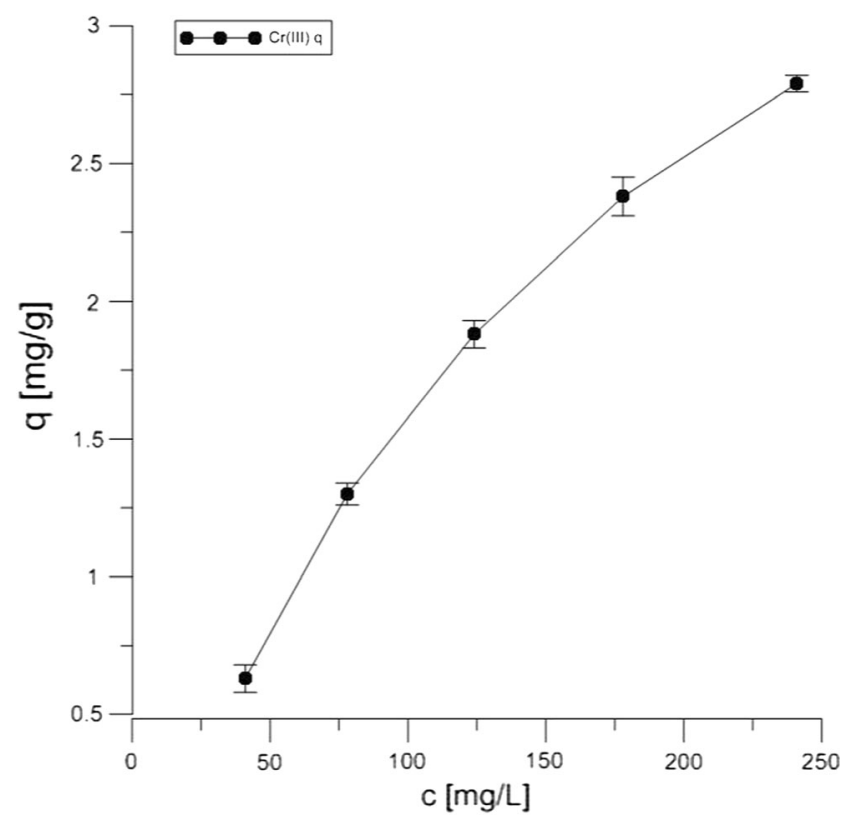

Fig. 4 Langmuir isotherm of $10 \mathrm{mM} \mathrm{Cr}$ (III) onto peat during $20 \mathrm{~h}$ of contact

The $R^{2}$ values from Table 2 show that the chromium ion sorption is well characterized by the Langmuir model, indicating the formation of a monolayer coverage of the adsorbate at the outer surface onto the peat and coconut fiber, respectively. The highest adsorption capacity was obtained for the Canadian peat treated with $\mathrm{NaCl}$ in comparison with the untreated material, as indicated by the $q_{0}$. Very similar data were observed in case of coconut fiber and $\mathrm{NaCl}$ (data not shown). A relatively low value of sorption equilibrium constant $K_{L}$

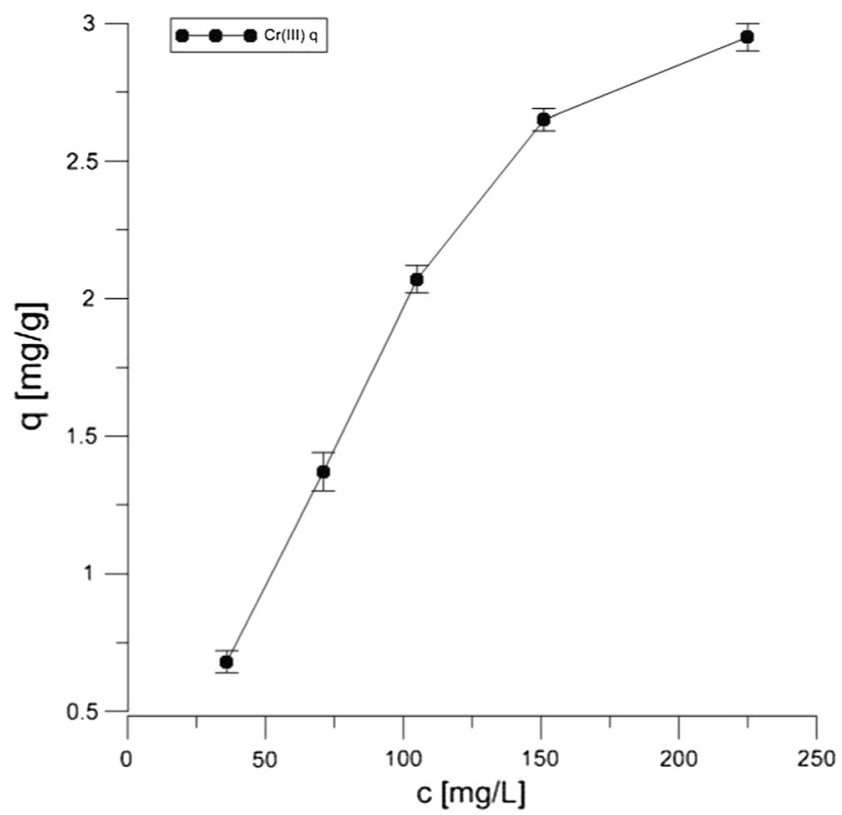

Fig. 5 Langmuir isotherm of $10 \mathrm{mM} \mathrm{Cr}(\mathrm{III})$ onto peat with $\mathrm{NaCl}$ during $20 \mathrm{~h}$ of contact 
suggests a weak interaction for both chromium forms with peat sorbent. However, $\mathrm{Cr}(\mathrm{VI})$ is more strongly bound on the adsorbent surface than the $\mathrm{Cr}$ (III) ion, probably additional chemical groups are involved in the adsorption processes, e.g., carboxylic and amine groups, thus, the $q_{0}$ indicates more active sites responsible for the binding. The observation is in accordance with the data of Kyziol et al. (2006), where the authors showed that not all carboxylic groups were involved in $\mathrm{Cr}$ (III) binding.

In the case of $\mathrm{Cr}(\mathrm{III})$ at $\mathrm{pH} 4.5$ ions existed as hydrocations $\left(\mathrm{Cr}\left(\mathrm{H}_{2} \mathrm{O}\right)_{6}{ }^{+3}\right.$ or $\left.\mathrm{Cr}(\mathrm{OH})\left(\mathrm{H}_{2} \mathrm{O}\right)_{5}{ }^{+2}\right)$, the constant of the first degree of hydrolysis is equal to $2.0 \times 10^{-4}$ in $25^{\circ} \mathrm{C}$ (Hiroishi et al. 1998) which means that at $\mathrm{pH} 3.7$, the solution might be an equimolar mixture of $\mathrm{Cr}\left(\mathrm{H}_{2} \mathrm{O}\right)_{6}{ }^{+3}$ or $\mathrm{Cr}(\mathrm{OH})\left(\mathrm{H}_{2} \mathrm{O}\right)_{5}{ }^{+2}$ while $\mathrm{Cr}\left(\mathrm{H}_{2} \mathrm{O}\right)_{6}{ }^{+3}$ could dominate only at lower $\mathrm{pH}$. The constant of the second stage of hydrolysis is equal to $2 \times 10^{-6}$, which means that at $\mathrm{pH} 5.8$ there is an equimolar mixture of $\mathrm{Cr}(\mathrm{OH})\left(\mathrm{H}_{2} \mathrm{O}\right)_{5}{ }^{+}$and $\mathrm{Cr}(\mathrm{OH})_{2}\left(\mathrm{H}_{2} \mathrm{O}\right)_{4}{ }^{+1}$ at the much lower concentration of $\mathrm{Cr}\left(\mathrm{H}_{2} \mathrm{O}\right)_{6}{ }^{+3}$ in comparison with the two above. Thus, at the range of 3.7-5.8, the $\mathrm{Cr}(\mathrm{OH})\left(\mathrm{H}_{2} \mathrm{O}\right)_{5}{ }^{+2}$ is a dominant form with the possibility of moving the equilibrium towards the $\mathrm{Cr}\left(\mathrm{H}_{2} \mathrm{O}\right)_{6}{ }^{+3}$ in the case of the occurrence of a factor (in our case the sorbent) shifting the balance in accordance with the contradiction rule and the diagram shown above. This shift and sorption as its consequence is the greater the more the $\mathrm{pH}$ is near the 3.7 value.

At this $\mathrm{pH}, \mathrm{Cr}(\mathrm{III})$ ions are bound to hydroxylic groups of peat as it was suggested in Scheme 2. In the experimental conditions, the strength of such a binding and the treatment of peat with $\mathrm{NaCl}$ result in a higher number of hydroxylic and carboxylic groups available for the interaction. Then the change of $q_{0}$ is observed. The bigger number of Cr(III) than $\mathrm{Cr}(\mathrm{VI})$ ions bound on the peat can suggest that the negatively charged groups of adsorbent, responsible for the $\mathrm{Cr}$ (III) binding, are exposed and divided into at least two classes. $\mathrm{Cr}(\mathrm{VI})$ anion is more strongly bound on the sites of "first class," e.g., amine-protonated groups, since the smaller number of the ions are bound. The opposite situation is observed in the case of $\mathrm{Cr}$ (III) which is positively charged - the higher number of ions are bound with sites of "second class" fully exposed to the surface, e.g., hydroxyl groups.

In the work of Cerqueira et al. (2012), the constant for $\mathrm{Cr}$ (III) was significantly higher than the values presented in Table 2. It indicates the strong interaction of chromium with the subtropical peat which the authors used in their experiments. As it is known, the organic composition of the peat depends on the environmental conditions in which the peat was formed. The source of such a discrepancy can be connected with the origin of the botanical formation of peat deposits, e.g., in this work, the peat was obtained from an arctic area.

Figure 5 illustrates the reduction process of tannery wastewater containing $0.458 \pm 0.002 \mathrm{mg} / \mathrm{l}$ of the total chromium. The signal coming from the $\operatorname{Cr}(\mathrm{V})$ ion suggests that the $\mathrm{Cr}(\mathrm{VI})$ is also present in the examined probe and its concentration reaches about $30 \%$ of the total chromium. The experiments carried out with the use of EPR L-band showed that the reduction of $\mathrm{Cr}(\mathrm{VI})$ starts in the first seconds after the addition of wastewater to the organic material. After $20 \mathrm{~h}$ of the reduction process, there were no signs of reduction which suggests that all of the hexavalent chromium was reduced to the trivalent chromium (Fig. 6).

In the case of both organic materials treated with the wastewater from the treatment plant, the reaction of $\mathrm{Cr}(\mathrm{V})$ formation starts right after the addition of waste to the organic materials. As can be seen in Fig. 7, there are two phases of the reduction process. The first phase is very rapid and starts right after the contact between organic materials and wastewater containing $\mathrm{Cr}(\mathrm{VI})$. The second phase starts after about $18 \mathrm{~min}$ and it is slower. After $160 \mathrm{~min}$ of the reduction measurement, the process was still ongoing. The complete reduction was observed after $20 \mathrm{~h}$ of the incubation process (data not shown). The two-phase reduction process can be explained in terms of chemical reduction (first phase) and activity of bacterial-yeast microorganisms which can reduce the $\mathrm{Cr}(\mathrm{VI})$ enzymatically. The similar phenomena were observed in the yeast reduction case.

As suggested by Sharma D.C. and Forster C.F. (1995) the chemical reduction of $\mathrm{Cr}(\mathrm{VI})$ is caused by the oxidation of peat particles and arising protons are responsible for the reduction: $\mathrm{HCrO}_{4}^{-}+7 \mathrm{H}^{+}+3 \mathrm{e}^{-} \mathrm{Cr}^{3+}+4 \mathrm{H}_{2} \mathrm{O}$

The slight differences between coconut fiber and Canadian peat could be connected with the differences in the presence of the hydroxyquinone/quinine redox couple which increases the reduction process at lower $\mathrm{pH}$ due to lowering of the redox potential of the $\mathrm{HCrO}_{4}$ species, which is predominant under acidic conditions (da Cerqueira et al. 2012)
Scheme 2 Mechanism of the $\mathrm{Cr}^{+}$ ${ }^{3}$ ions interaction with the organic material

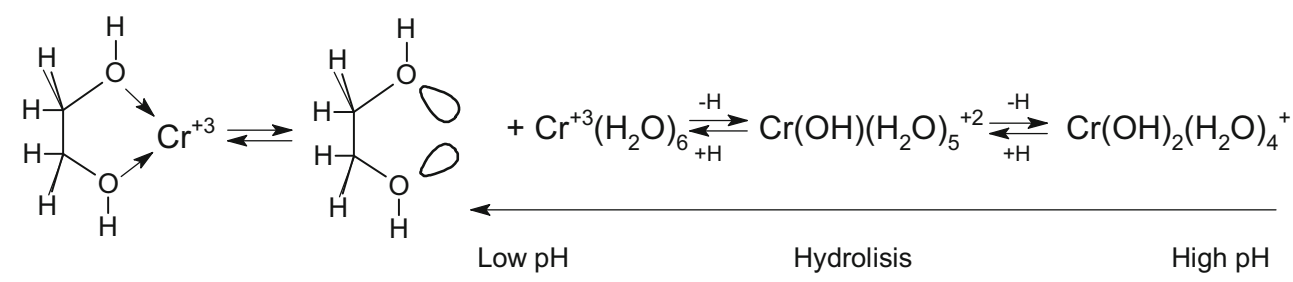




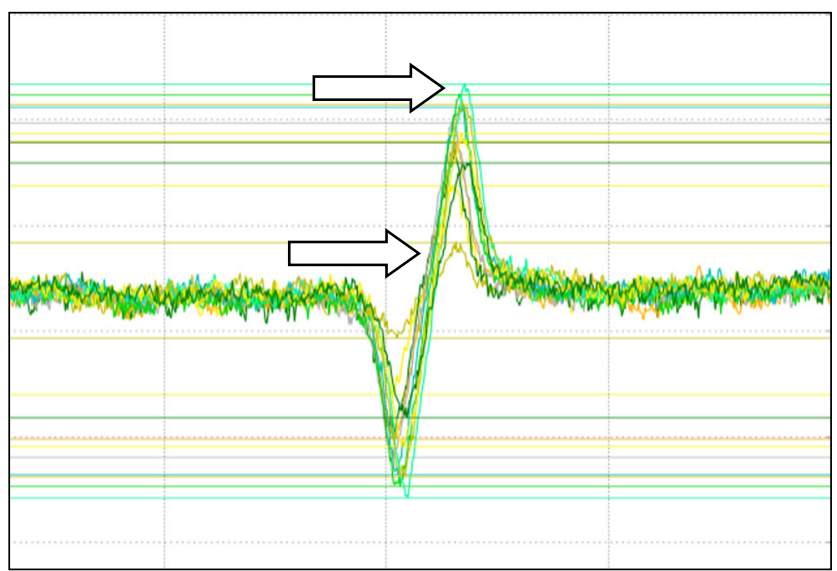

Fig. 6 Reduction of $\mathrm{Cr}(\mathrm{VI})$ from wastewater by peat $(\mathrm{pH}=4.6)$ measured with EPR L-band spectra of $\mathrm{Cr}(\mathrm{V})$. The upper arrow indicates the maximum reduction of $\mathrm{Cr}(\mathrm{VI})$ in the middle of the experiment. The lower arrow indicates the minimum reduction of $\mathrm{Cr}(\mathrm{VI})$ at the end of the reduction process. The time of the reduction process was equal to $180 \mathrm{~min}$

\section{Desorption studies}

In order to check the possibility of reusing both of the organic materials (Canadian peat, coconut fiber), several elutions with demineralized water were made. Portions of $10 \mathrm{ml}$ of demineralized water were added to the SPE columns containing materials with adsorbed chromium ions. After each rinse, the filtrate was tested for the presence of chromium compounds using the above-mentioned

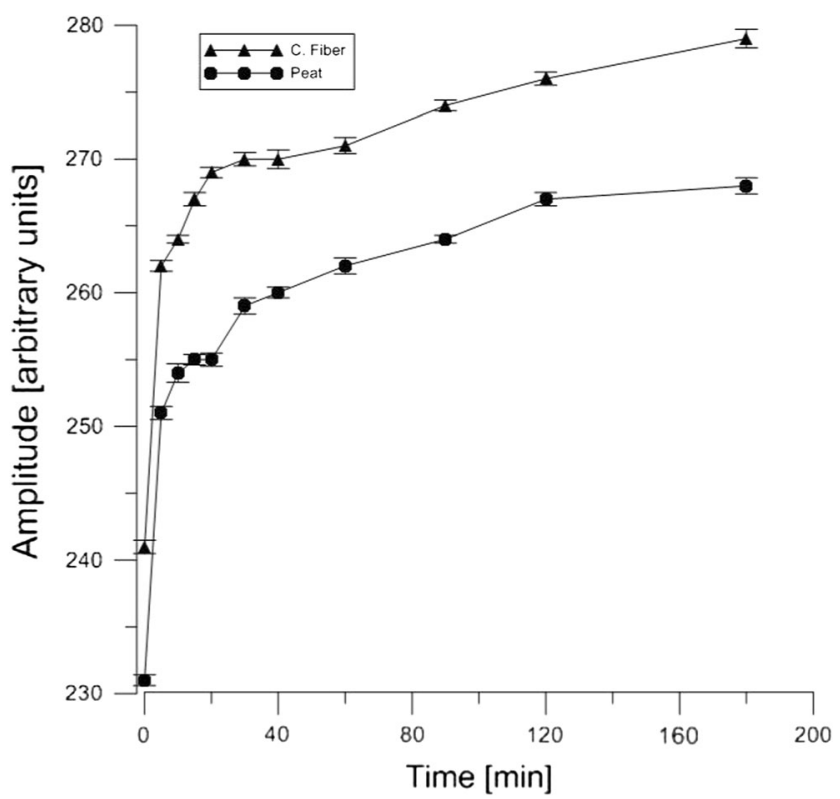

Fig. 7 Comparison of the reduction process of $10 \mathrm{mM} \mathrm{Cr}(\mathrm{VI})$ by the Canadian peat and coconut fiber methods. After the third washing, there were no signs of $\mathrm{Cr}$ in the filtrate. The sum of the chromium content in the filtrates was roughly equal to the amount of chromium applied to the column. The results indicate that both chromium (VI) and (III) ions can be easily eluted. This fact is in agreement with the low interaction between ions and the binding sites on the organic material surface. After the recovery, both organic materials can be used again for chromium adsorption without any loss in the metal uptake. The obtained results show that both materials can be used as biofilters in the wastewater treatment plants for removal of $\mathrm{Cr}(\mathrm{III})$ and $\mathrm{Cr}(\mathrm{VI})$ ions.

\section{Conclusions}

Both Canadian peat and coconut fiber were able to remove $\mathrm{Cr}(\mathrm{VI})$ and $\mathrm{Cr}(\mathrm{III})$ from aqueous solution in simultaneous processes of reduction and adsorption onto the material. The coconut fiber was slightly better in terms of adsorption of both $\mathrm{Cr}(\mathrm{VI})$ and $\mathrm{Cr}(\mathrm{III})$ and reduction of $\mathrm{Cr}(\mathrm{VI})$. The adsorption of chromium (VI) could be mainly explained by the fact that there was an interaction between the hydroxyl groups of carbohydrates present in the studied organic matters and central chromium ion. The carboxylic and amine groups of organic matter were also involved with regard to adsorption in the case of cationic (III) forms of the metal. The reduction of $\mathrm{Cr}(\mathrm{VI})$ is a twophase process. The first phase is a rapid chemical reaction, whereas the second phase is longer and probably based on enzymatic reactions.

The results show that both materials can be used as biofilters' bed in the wastewater treatment plants for removal of both $\mathrm{Cr}(\mathrm{III})$ and $\mathrm{Cr}(\mathrm{VI})$ ions as well as reduction of the latter form of the metal. Although adsorption reaction is very effective at low $\mathrm{pH}$ as can be seen in Figs. 1 and 2, the process of decreasing the $\mathrm{pH}$ value to 1.5 is expensive. It seems that the appropriate corrections of $\mathrm{pH}$ values are needed to establish the sorption and desorption states of an organic solid bed, e.g., $\mathrm{pH} 4.5$ is equivalent to $0.03 \mathrm{mmol} / \mathrm{dm}^{3} \mathrm{H}_{3} \mathrm{O}^{+}$concentration, and therefore, a moderate amount of reagents allows $\mathrm{pH}$ change from 7 to 4.5 , necessary for the purification process. The proposed models of chemical sorption/desorption states make it possible to select the materials that can be used in the adsorption and reduction processes, the selection being based on the chemical structure of a sorbent.

Open Access This article is distributed under the terms of the Creative Commons Attribution 4.0 International License (http:// creativecommons.org/licenses/by/4.0/), which permits unrestricted use, distribution, and reproduction in any medium, provided you give appropriate credit to the original author(s) and the source, provide a link to the Creative Commons license, and indicate if changes were made. 


\section{References}

Balan C, Bilba D, Macoveanu M (2009) Studies on chromium (III) removal from aqueous solutions by sorption on Sphagnum moss peat. J Serb Chem Soc 74(8-9):953-964

Brown PA, Gill SA, Allen SJ (2000) Metal removal from wastewater using peat. Water Res 34(16):3907-3916

Chwastowski J, Kołoczek H (2013) The kinetic reduction of Cr(VI) by yeast Saccharomyces cerevisiae, Phaffiarhodozyma and their protoplasts. Acta Biochim Pol 60(4):829-834

da Cerqueira SCA, Romao LPC, Lucas SCO, Fraga LE, Simoes ML, Hammer P, Lead JR, Mangoni AP, Mangrich AS (2012) Spectroscopic characterization of the reduction and removal of chromium (VI) by tropical peat and humin. Fuel 91:141-146

Gomez V, Callao MP (2006) Chromium determination and speciation since 2000. TRAC-Trends Anal Chem 25(10):1006

Hiroishi D, Matsuura C, Ishigure K (1998) Hydrolisis of chromium(III) ion and solubility of chromium(III) oxide in high temperature water. Mineral Mag 62A:626-627

Kotas J, Stasicka Z (2000) Chromium occurrence in the environment and methods of its speciation. Environ Pollut Mar 107(3):263-283

Kyziol J, Twardowska I, Schmitt-Kopplin P (2006) The role of humic substances in chromium sorption onto natural organic matter (peat). Chemosphere 63:1974-1982

Levina A, Lay PA (2004) Solution structures of chromium(VI) complexes with glutathione and model thiols. Inorg Chem 43(1):324 335

Milacic R, Stupar J (1995) Fractionation and oxidation of chromium in tannery waste- and sewage sludge-amended soils. Environ Sci Technol 29(2):506-514

Mohan D, Pittman CU Jr (2006) Activated carbons and low-cost adsorbents for remediation of tri- and hexavalent chromium from water: a review. J Hazard Mater B 137:762-811
Nakayasu K, Fukushima M, Sasaki K, Tanaka S, Nakamura H (1999) Comparative studies of the reduction behavior of chromium (VI) by humic substances and their precursors. Environ Toxicol Chem 18: $1085-1090$

Richard FC, Bourg ACM (1991) Aqueous geochemistry of chromium: a review. Water Res 25:807-816

Sharma DC, Forster CF (1995) Column studies into the adsorption of chromium (VI) using sphagnum peat. Bioresource Technol 52: 261-267

Silva B, Figueiredo H, Quintelas C, Neves IC, Tavares T (2008) Iron and chromium removal from binary solutions of $\mathrm{Fe}(\mathrm{III}) / \mathrm{Cr}$ (III) and $\mathrm{Fe}(\mathrm{III}) / \mathrm{Cr}(\mathrm{VI})$ by biosorbents supported on zeolites. Mater Sci Forum 587-588:463-467

Singh KP, Mohan D, Sinha S, Dalwani R (2004) Impact assessment of treated/untreated wastewater toxicants discharged by sewage treatment plants on health, agricultural, and environmental quality in the wastewater disposal area. Chemosphere 55:227-255

Sollitto D, Romic M, Castrignanò A, Romic D, Bakic H (2010) Assessing heavy metal contamination in soils of the Zagreb region (Northwest Croatia) using multivariate geostatistics. CATENA 80:182-194

Stearns DM, Wetterhahn KE (1994) Reaction of chromium(VI) with ascorbate produces chromium(V), chromium(IV), and carbonbased radicals. Chem Res Toxicol 7:219-230

Yuan P, Fan M, Yang D, He H, Liu D, Yuan A, Zhu J, Chen T (2009) Montmorillonite-supported magnetite nanoparticles for the removal of hexavalent chromium [Cr(VI)] from aqueous solutions. J Hazard Mater 166:821-829

Yuan P, Liu D, Fan M, Yang D, Zhu R, Ge F (2010) Removal of hexavalent chromium $[\mathrm{Cr}(\mathrm{VI})]$ from aqueous solutions by the diatomite-supported/unsupported magnetite nanoparticles. J Hazard Mater 173:614-621 